JKEP

Vol 3, No 2, November 2018

ISSN: 2354-6042 (Print)

ISSN : 2354-6050 (Online)

\title{
Pengaruh Terapi Musik Klasik Beethoven untuk Mengurangi Kecemasan pada Ibu Bersalin Pre Operasi Sectio Caesar
}

\author{
Keumalahayati, Supriyanti \\ Poltekkes Kemenkes Aceh \\ Email: k_mala70@yahoo.coid
}

\begin{abstract}
Artikel history
Dikirim, Sep $22^{\text {th }}, 2018$

Ditinjau, Okt $10^{\text {th }}, 2018$

Diterima, Okt $26^{\text {th }}, 2018$
\end{abstract}

\begin{abstract}
Anxiety in preoperative patients with Sectio Caesarea is a specific anxiety, namely concern about operating procedures, anesthesia procedures, information deficits, and concerns about family financial problems, concerns about themselves and the baby to be born. Music is applied into therapy, because music can restore, and maintain physical, mental, emotional, social and spiritual health. The provision of classical music therapy can releases pain and reduces stress levels, so that it can cause a decrease in anxiety. The purpose of this study was to determine the effect of Beethoven classical music therapy to reduce anxiety in cesarean section. This study used a preexperimental design with the design of two group control interventions. The number of samples in this study were 10 people each in the intervention and control groups. Sampling is done using accidental techniques. Data analysis using the t-dependent test. The t-dependent statistical test results can be concluded that there is a significant influence of classical music therapy to reduce anxiety in cesarean section delivery mothers in the intervention and control groups $(P=0.041)$. From the results of this study it is known that Beethoven classical music therapy is effective for reducing anxiety, so that nurses can apply classical music therapy in providing care to cesarean section mothers.
\end{abstract}

Keywords : Therap; music classics; anxiety; maternity.

\begin{abstract}
ABSTRAK
Kecemasan pasien pre operasi Sectio Caesarea umumnya spesifik seperti kekhawatiran terhadap prosedur operasi, prosedur anastesi, defisit informasi,dan kekhawatiran tentang masalah finansial keluarga, kekhawatiran terhadap diri dan bayi yang akan dilahirkannya. Musik diterapkan menjadi terapi, karena dapat memulihkan, dan memelihara kesehatan fisik, mental, emosional, sosial dan spiritual. Pemberian intervensi terapi musik dapat mengurangi nyeri dan menurunkan tingkat stress, sehingga
\end{abstract}


dapat menurunkan kecemasan. Tujuan penelitian ini untuk mengetahui pengaruh terapi musik klasik Beethoven untuk mengurangi kecemasan pada ibu bersalin seksio sesarea. Penelitian ini menggunakan desain pra exsperimental design dengan rancangan two group intervensi kontrol. Jumlah sampel dalam penelitian ini adalah masing-masing 10 orang pada kelompok intervensi dan kontrol. Pengambilan sampel dilakukan dengan menggunakan teknik aksidental. Analisis data menggunakan uji t-dependent. Hasil uji statistik t-dependent dapat disimpulkan bahwa ada pengaruh terapi musik klasik yang signifikan untuk mengurangi kecemasan pada ibu bersalin seksio sesarea pada kelompok intervensi dan kontrol $(\mathrm{P}=0.041)$. Dari hasil penelitian ini diketahui bahwa terapi musik klasik Beethoven efektif untuk mengurangi kecemasan, sehingga perawat dapat menerapkan terapi musik klasik dalam memberikan asuhan kepada ibu bersalin seksio sesarea.

Kata Kunci : Terapi; musik klasik; kecemasan; ibu bersalin.

\section{PENDAHULUAN}

Persalinan Secsio Cesarea (SC) adalah suatu cara melahirkan janin dengan membuat sayatan pada dinding uterus melalui dinding depan perut, seksio sesarea juga dapat didefenisikan sebagai suatu histerotomia untuk melahirkan janin dari dalam Rahim (Sofian, 2012). SC menjadi pertimbangan yang lebih diutamakan karena dapat menyelamatkan jiwa ibu maupun janin. Akan tetapi persalinan melalui SC bukanlah alternatif yang lebih aman karena perawatan operasi SC diperlukan pengawasan khusus terhadap indikasi dan perawatan post operasi SC karena pengawasan yang tidak sesuai akan berdampak pada kematian (Wiknjosastro, 2005).

Data statistik tentang 3.509 kasus SC menyebutkan bahwa indikasi umum SC antara lain: Disproporsi kepala janin dan panggul ibu 21\%, Disfungsi uterus (kontraksi rahim kurang memadai) 14\%, Distosia serviks (kanker leher rahim), Plasenta previa (plasenta menutup jalan lahir) 11\%, Riwayat bedah sesar $11 \%$, Pre eklamsi (tekanan darah yang tinggi disertai kejang) 10\%, Janin besar (>3.500 gr), Fetal disterss atau stress janin (detak jantung bayi terganggu), Kelainan letak (sungsang atau lintang) 10\% (Wiknjosastro, 2005). Komplikasi akibat persalinan SC yang bisa terjadi pada bayi adalah bayi menjadi kurang aktif dan lebih banyak tidur akibat dari efek anestesi, sehingga akan mempengaruhi pemberian ASI. Bayi yang dilahirkan melalui SC sering mengalami gangguan pernafasan karena kelahiran yang terlalu cepat. Bayi tidak beradaptasi pada saat proses transisi dari dunia dalam rahim menjadi di luar rahim yang dapat menyebabkan takipneu pada bayi. Komplikasi yang 
timbul setelah dilakukannya SC pada ibu seperti nyeri pada daerah insisi, potensi terjadinya thrombosis, potensi terjadinya penurunan kemampuan fungsional, penurunan elastisitas otot perut dan otot dasar panggul, perdarahan, luka kandung kemih, infeksi, bengkak pada ektremitas bawah, dan gangguan laktasi (Wiknjosastro, 2005).

Angka kesakitan dan kematian karena operasi seksio sesarea lebih tinggi dibandingkan dengan persalinan pervaginam.Menurut Benson dan Pernoll (2008), angka kematian operasi seksio sesarea berkisar 40-80 tiap 100.000 kelahiran hidup. Pasien seksio sesarea mempunyai risiko 25 kali lebih besar mengalami kematian dibandingkan persalinan pervaginam. Angka kesakitan pasien seksio sesarea sebesar 27,3 per 1.000 kejadian, jauh berbeda dengan angka kesakitan pada persalinan normal yang hanya 9 per 1.000 kejadian (Bobak, 2005). World Health Organization (WHO) menetapkan standar rata-rata sectio caesarea di sebuah Negara adalah sekitar 10\%-15\% per 1000 kelahiran di dunia. Menurut WHO peningkatan persalinan dengan sectio caesarea di seluruh Negara selama tahun 2007 2008 yaitu 110.000 per kelahiran di seluruh Asia (WHO, 2012).

Di Indonesia angka kejadian sectio caesarea mengalami peningkatan, pada tahun 2000 jumlah ibu bersalin dengan sectio caesarea 47,22\%, tahun 2001 sebesar 45,19\%, tahun 2002 sebesar 47,13\%, tahun 2003 sebesar 46,87\%, tahun 2004 sebesar 53,2\%, tahun 2005 sebesar 51,59\%, dan tahun 2006 sebesar 53,68\% dan tahun 2007 belum terdapat data yang signifikan. Survei Nasional pada tahun 2009, 921.000 persalinan dengan sectio caesarea dari 4.039.000 persalinan atau sekitar $22,8 \%$ dari seluruh persalinan (Grace, 2007). Hasil Riskesdas 2013 menunjukkan kelahiran bedah caesar sebesar $9,8 \%$ dengan proporsi tertinggi di DKI Jakarta $(19,9 \%)$ dan terendah di Sulawesi Tenggara $(3,3 \%)$, sedangkan di NAD $(9,6 \%)$ dan angka kejadian persalinan sectio caesarea menurut data RSUD Langsa tahun 2014 jumlah ibu bersalin sectio caesarea adalah 875 dan diantaranya persalinan sectio caesarea untuk ibu primigravida adalah 540 orang. Secara umum pola persalinan melalui bedah sesar menurut karakteristik menunjukkan proporsi 
tertinggi pada kuintil indeks kepemilikan teratas $(18,9 \%)$, tinggal di perkotaan $(13,8 \%)$, pekerjaan sebagai pegawai $(20,9 \%)$ dan pendidikan tinggi/lulus PT $(25,1 \%)$. Peningkatan ini disebabkan oleh teknik dan fasilitas operasi bertambah baik, operasi berlangsung lebih asepsis, teknik anestesi bertambah baik, kenyamanan pasca operasi dan lama perawatan yang menjadi lebih singkat. Di samping itu morbiditas dan mortalitas maternal dan perinatal dapat diturunkan secara bermakna. ${ }^{7}$ Kondisi nyeri yang hebat pada kala 1 persalinan juga meningkatkan para ibu cenderung memilih cara yang paling gampang dan cepat untuk menghilangkan rasa nyeri. Fenomena yang terjadi saat ini ibu memiliki kecenderungan untuk melakukan SC walau tanpa indikasi yang jelas (Gant, N., \& Cunningham, F., 2010).

Kecemasan pasien pre operasi SC merupakan kecemasan yang spesifik yakni kekhawatiran terhadap prosedur operasi, prosedur anatesi, defisit informasi atau kesalah pahaman konsep, kekhawatiran tentang masalah finansial keluarga, kekhawatiran terhadap diri dan bayi yang akan dilahirkannya
(Potter, P.A., \& Perry, A.G., 2005). Hasil penelitian yang dilakukan Fauzi (2006), menunjukkan bahwa pelatihan dengan musik memberi lebih dari sekedar hubungan sebab akibat terhadap perkembangan bagian-bagian tertentu dari otak secara jangka panjang. Namun dengan mendengarkan musik akan membantu perkembangan positif dari otak manusia (Wijaya, 2008). Sedangkan pada penelitian yang dilakukan oleh Thomatis dan Campbell (1971), dengan tujuan penelitiannya untuk mengetahui efektifitas Mozzart effect untuk meningkatkan stimulasi (rangsangan) lebih tenang menghadapi persalinan. Penelitiannya melibatkan 11 ibu bersalin, didapat hasil bahwa ibu bersalin yang telah didengarkan musik klasik selama 10 menit, mengalami stimulasi (rangsangan) lebih tenang menghadapi persalinan.

Musik dapat mempengaruhi gelombang dalam otak hingga meningkatkan daya berpikir dan ketajaman berkonsentrasi lebih tinggi. Penelitian ini juga menyebutkan bahwa pada gelombang nada rendah seseorang dapat berada pada level ketenangan untuk bisa melakukan meditasi secara baik. Musik juga akan mempengaruhi ambang 
munculnya stress dan tekanan psikis lainnya, menyokong terjadinya relaksasi otot dan menekan emosi sehingga dimanfaatkan untuk mengurangi kecemasan dan rasa takut (Musbikin, 2009). Para dokter di masa Yunani dan Romawi Kuno menganjurkan metode penyembuhan dengan mendengarkan permainan alat musik seperti harpa atau seruling. Peneliti dari Skotlandia, Maxwell, sukses melakukan terapi penyembuhan epilepsi, lumpuh, depresi, bahkan beberapa jenis demam dengan permainan musik. Secara psikologis, pengaruh penyembuhan musik pada tubuh ada pada kemampuan saraf menangkap efek akustik. Kemudian, dilanjutkan dengan respon tubuh terhadap gelombang musik, yaitu dengan meneruskan gelombang tersebut keseluruh sistem kerja tubuh. Tetapi, tidak semua jenis musik memberi efek terapi penyembuhan. Beberapa penelitian menyebutkan bahwa musik klasik dan musik tradisional memberi pengaruh paling baik (Musbikin, 2009).

Terapi musik dipergunakan untuk individu dengan tujuan menyembuhkan, merehabilitasi, mendidik dan melatih anak-anak dan orang dewasa yang menderita gangguan fisik, mental atau emosional. Terapi musik juga pada dasarnya tidak hanya membantu mengatasi kebosanan, mengusir kesedihan atau melepaskan stress. Berikut ini beberapa penyakit yang berhasil disembuhkan dengan terapi musik yaitu penyakit jantung, pikun, autis, kanker, stress atau kecemasan dan nyeri (Musbikin, 2009).

Pasien pre operasi SC dipilih dalam penelitian karena kecemasan yang lebih tinggi. Teknik terapi musik Beethoven diharapkan dapat menurunkan kecemasan pasien pre operasi SC. Dari survey pendahuluan, yang dilakukan peneliti pada tanggal 15 Maret 2015 di RSUD Kota Langsa dengan metode wawancara pada 10 ibu yang mempunyai pengalaman operasi sectio caesarea, 10 orang ibu mengatakan mengalami kecemasan atau ketakutan akan keberhasilan operasi sectio caesarea dan mereka tidak pernah mendapatkan terapi music. Hal ini yang melatar belakangi untuk dilakukannya penelitian tentang Pengaruh terapi musik klasik Beethoven untuk mengurangi kecemasan pada ibu bersalin pre operasi sectio caesarea di RSUD Langsa tahun 2015. 


\section{METODE}

Desain penelitian ini adalah Pra Exsperimental Design yang bertujuan untuk memperoleh informasi dan mengetahui efektifitas musik klasik dalam mengurangi kecemasan ibu bersalin pre operasi SC di RSUD Langsa. Jenis yang dipakai dalam penelitian ini adalah Static Group Comparison. Rancangan ini menambahkan kelompok kontrol atau kelompok pembanding. Kelompok eksperimen menerima perlakuan (X) yang diikuti dengan pengukuran kedua atau observasi (O2). Hasil observasi ini kemudian dikontrol atau dibandingkan dengan hasil observasi pada kelompok kontrol, yang tidak menerima program atau intervensi.

Sampel adalah ibu ibu bersalin pre operasi sectio caesarea. Jumlah sampel adalah 20 responden. 10 responden pada kelompok intervensi dan 10 responden pada kelompok kontrol. Teknik pengambilan sampel peneliti menggunakan Accidental Sampling.

Pengumpulan data dalam penelitian ini menggunakan kuesioner menurut skala HARS. Uji statistik yang digunakan adalah rumus t-test dependent dengan tujuan untuk membandingkan perbedaan kecemasan antara kelompok kontrol dan intervensi, dengan tingkat kepercayaan $95 \%$ atau dapat pula dengan membandingkan nilai $p$-value dengan membandingkan $\alpha=0,05$.

Peneliti menekankan beberapa masalah etika yang meliputi bila calon responden bersedia menjadi responden maka lembar persetujuan akan ditanda tangani namun bila calon responden menolak maka tidak akan memaksa dan tetap menghormati haknya, tidak mencantumkan nama responden pada lembar kuesioner yang diberikan tetapi hanya memberikan kode, peneliti menjamin kerahasian informasi yang diberikan oleh responden, calon responden diberi kebebasan untuk menentukan apakah bersedia atau tidak untuk mengikuti kegiatan penelitian secara sukarela. Responden dijaga ketat yaitu dengan cara merahasiakan informasi-informasi yang di dapat dari responden hanya untuk kepentingan penelitian. Peneliti menekankan bahwa apabila responden merasa tidak aman dan nyaman selama penelitian berlangsung yang dapat menimbulkan gejala psikologis maka calon responden di ajukan untuk memilih menghentikan 
partisipasinya atau terus melanjutkan.

\section{HASIL DAN PEMBAHASAN}

1. Proporsi Tingkat Kecemasan Pasien pada Kelompok Intervensi dan Kontrol

Tabel 1 menunjukan proporsi tingkat kecemasan pada kelompok intervensi

Tabel 1

Tingkat Kecemasan Pasien pada Kelompok Intervensi dan Kontrol

\begin{tabular}{ccccc}
\hline \multirow{2}{*}{ Kategori } & \multicolumn{4}{c}{ Sampel } \\
\cline { 2 - 5 } & \multicolumn{2}{c}{ Intervensi } & \multicolumn{2}{c}{ Kontrol } \\
\cline { 2 - 5 } & $\mathrm{f}$ & $\%$ & $\mathrm{f}$ & $\%$ \\
\hline Kecemasan Sedang & 3 & 30 & 1 & 10 \\
Kecemasan Berat & 6 & 60 & 2 & 20 \\
Kecemasan Berat Sekali & 1 & 10 & 7 & 70 \\
Total & 10 & 100 & 10 & 100 \\
\hline
\end{tabular}

Pada kelompok intervensi rata - rata kategori kecemasan berada pada tingkat kecemasan berat dan sedang. Sementara pada kelompok kontrol berada pada kategori kecemasan berat sekali.

2. Pengaruh Terapi Musik Klasik Beethoven Untuk Mengurangi Kecemasan Ibu Bersalin Pre SC Tabel 2 menjelaskan hasil observasi pengukuran kecemasan dengan menggunakan kuesioner kecemasan. Uji paired T-Test didapatkan nilai yang dominan adalah kecemasan berat sebesar $60 \%$ dan kecemasan sedang sebesar $30 \%$. Sementara pada kelompok kontrol yang paling banyak adalah tingkat kecemasan berat sekali sebesar $70 \%$ dan kecemasan berat sebanyak $30 \%$. 
Tabel 2

Pengaruh Terapi Musik Klasik Beethoven untuk

Mengurangi Kecemasan Ibu Bersalin Pre SC

\begin{tabular}{ccccccc}
\hline & Mean & SD & \multicolumn{2}{c}{$95 \%$} & t & p-value \\
\cline { 2 - 7 } Skala Kecemasan & & & Min & Maks & & \\
\hline Kelompok Intervensi & 3,80 & 0,632 & $-0,0121$ & 1,612 & 2,228 & 0,041 \\
Kelompok Kontrol & 4,60 & 0,699 & & & & \\
\hline
\end{tabular}

Pengaruh terapi musik klasik Beethoven terhadap penurunan kecemasan ibu bersalin pre operasi sectio caesarea, dikarenakan musik dapat berpengaruh untuk merangsang otak dan mampu mengaktifkan fungsi otak yang telah mengalami penurunan akibat adanya gangguan fisik. Gangguan fisik ini akan merangsang fungsi kognitif, merangsang penginderaan dan akan disampaikan keotak dengan menggunakan sinyal saraf, merangsang berfikir dan tidak dapat dipungkiri bahwa ketika seseorang mendengarkan musik klasik, maka seseorang akan mengawali proses berfikir seperti mengikuti irama musik. Dengan metode terapi musik klasik Beethoven, ibu bersalin bisa mendapatkan relaksasi yang mendalam. Baik secara fisik, jiwa dan pikiran, dalam keadaan relaksasi yang dalam ini seorang ibu bisa mengaktifkan pikiran bawah sadarnya. Dampak melalui pikiran bawah sadar yang aktif, ibu bersalin dengan mudah mendapatkan suasana rileks, emosi stabil, nyaman dan bahagia, dikarenakan endorphin yang muncul 200 kali lebih besar dari pada morfin ataupun terapi farmakologi lainnya.

Asumsi peneliti bahwa musik sebagai gelombang suara dapat meningkatkan suatu respon seperti peningkatan endorphin yang dapat mempengaruhi suasana hati dan dapat menurunkan kecemasan pasien. Musik memiliki sifat yang universal dan sangat mudah diterima oleh organ pendengaran dan tidak dibatasi pula oleh fungsi intelektual. Musik klasik memiliki kejernihan keanggunan, dan kebeningan, musik ini mampu memperbaiki konsentrasi, ingatan, dan persepsi. Pada dasarnya semua jenis musik sebenarnya dapat digunakan dalam usaha menurunkan kecemasan. Musik klasik sering menjadi acuan karena berirama tenang dan mengalun lembut. Pemilihan musik klasik lebih 
didasarkan pada keyakinan banyak ahli bahwa irama dan tempo kebanyakan musik klasik mengikuti kecepatan detak jantung manusia yaitu sekitar 60 detak/menit.

Relaksasi bertujuan untuk memberikan perasaan nyaman, mengurangi respon stres, khususnya stres ringan, memberikan ketenangan, dan mengurangi ketegangan. Efektifitas teknik relaksasi yang umumnya dapat dirasakan oleh setiap individu adalah perubahan pada respon fisiologis tubuh. Ide dasar dari teknik relaksasi adalah untuk mempelajari cara mengalihkan pikiran sehingga individu dapat menyingkirkan respon stres yang mengganggu pikiran: Efek positif yang diperoleh dari teknik relaksasi berupa perbaikan fungsi dari sistem saraf yang secara otomatis menurunkan respon stres.

Relaksasi mampunyai efek sensasi menenangkan anggota tubuh, ringan dan merasa kehangatan yang menyebar ke seluruh tubuh. Perubahan-perubahan yang terjadi selama maupun setelah relaksasi mempengaruhi kerja saraf otonom. Respon emosi dan efek menenangkan yang ditimbulkan oleh relaksasi ini mengubah fisiologi dominan simpatis menjadi dominan sistem parasimpatis. Dalam keadaan ini, hipersekresi katekolamin dan kortisol diturunkan dan meningkatkan hormone parasimpatis serta neurotransmiter seperti DHEA, hormon pertumbuhan, dan dopamine. Regulasi sistem parasimpatis ini akhirnya menimbulkan efek ketenangan. Saat mencapai kondisi rileks yang dalam dan stabil, suatu konsep baru yang secara otomatis mempengaruhi kehidupan dan tindakan sehari-hari akan mampu ditanamkan

Intervensi dengan teknik relaksasi terapi musik juga dapat mengubah secara efektif ambang otak kita yang dalam keadaan stress menjadi secara fisiologis lebih adaptif. Musik begitu mudah diterima organ pendengaran kita dan melalui saraf pendengaran diterima dan diartikan di otak dan musik dapat masuk langsung ke otak emosi kita atau sistem limbik. Musik dapat pula beresonansi dan bersifat naluriah, sehingga efek terapi masuk otak.

Hasil penelitian sesuai dengan pendapat Snyder \& Lindquist (2002) yang mengungkapkan bahwa melalui relaksasi individu dapat mencapai 
keadaan tenang. Pada kondisi cemas, stres dan depresi secara fisiologis tubuh akan mengalami respon yang dinamakan fight or flight. Metabolisme tubuh meningkat sebagai persiapan untuk pemakaian energi pada tindakan fisik. Kecepatan denyut jantung, tekanan darah, frekuensi pernafasan meningkat, serta otot menjadi tegang. Sebagian besar perubahan fisiologis tersebut akibat sistem saraf simpatis. Aktifnya sistem saraf simpatis membuat individu tidak dapat santai dan tenang. Melalui respon relaksasi terjadi perubahan fisiologis tubuh dengan aktifnya sistem parasimpatis. Kebutuhan oksigen tubun menurun, sirkulasi aliran darah lancar, neurotransmitter penenang dilepaskan dan berdampak pada otot-otot tubuh yang rileks menimbulkan perasaan tenang dan nyaman.

Hasil penelitian ini juga sejalan dengan penelitian yang dilakukan oleh Nasution (2011) dengan judul Efektifitas Terapi Musik Klasik Untuk Mengurangi Kecemasan Pada Ibu Bersalin Sectio Caesarea di RSUD dr.Pringadi Medan, yang melaporkan bahwa ada pengaruh terapi musik klasik terapi musik klasik yang signifikan untuk mengurangi kecemasan pada ibu bersalin sectio caesarea pada kelompok kontrol dan intervensi $(\mathrm{p}=0,000)$. Dari hasil penelitian ini diketahui bahwa terapi musik klasik efektif untuk mengurangi kecemasan, sehingga perawat atau tenaga kesehatan dapat menerapkan terapi musik klasik dalam memberikan asuhan kepada ibu bersalin sectio caesarea. Hal ini juga sesuai dengan pendapat Musbikin, (2009) bahwa pemberian intervensi terapi musik klasik membuat seseorang menjadi rileks, menimbulkan rasa aman dan sejahtera, melepaskan rasa gembira dan sedih, melepaskan rasa sakit dan menurunkan tingkat stress, sehingga dapat menyebabkan penurunan kecemasan. Hasil penelitian ini sesuai dengan pendapat Aizid (2011) bahwa teknik relaksasi dapat menurunkan kecemasan, nyeri fisiologis, stress dan depresi. Diperkuat dengan penelitian Muna (2012) dan Pratiwi (2012) yang membuktikan penurunan kecemasan menggunakan teknik relaksasi.

\section{SIMPULAN}

Berdasarkan hasil penelitian dan pembahasan, maka dapat disimpulkan bahwa tingkat kecemasan berat sekali dijumpai pada ibu di kelompok kontrol 
(70\%), sementara pada kelompok intervensi yang paling banyak adalah tingkat kecemasan berat $60 \%$. Ada perbedaan yang signifikan antara tingkat kecemasan kelompok kontrol dan kelompok intervensi pada ibu yang pre operasi secsio sesaria di RSUD Kota Langsa Tahun 2015 ( $\mathrm{p}=0,041)$.

\section{UCAPAN TERIMAKASIH}

Terimakasih peneliti ucapkan kepada berbagai pihak yang telah memberikan bantuan pada penelitian yang dilakukan yaitu kepada Tim Reviewer, Direktur RSUD Langsa, Kepala dan Staf Ruang Kebidanan RSUD Kota Langsa serta seluruh pihak-pihak terkait lainnya.

\section{DAFTAR RUJUKAN}

Andriana, E. 2010. Melahirkan tanpa rasa sakit. Jakarta : Bhuana Ilmu Populer.

Aizid, R. 2011. Sehat dan cerdas dengan terapi musik. Jogjakarta : Laksana.

Bobak, I.M, Deitra, L.L, \& Margaret, D.J. 2005. Buku Ajar Keperawatan Maternitas. Ed ke4. Jakarta: EGC.

Cendikia, D.I. 2010. Panduan Pintar Hamil dan Melahirkan. Jakarta: Wahyu Media.

Chapman, Vicky. 2006. Asuhan Kebidanan : Persalinan dan Kelahiran. Jakarta : EGC.
Doengoes, M.E. 2007. Rencana Asuhan Keperawatan Psikiatri. Jakarta: EGC.

Dwi, A. (2011). Terapi Modalitas Keperawatan Komunitas. Jakarta : Program Spesialis Komunitas FIK Universitas Indonesia.

Fauzi, D.A. (2006). Pengaruh Musik Bagi Kecerdasan Bayi. Jakarta: Harmoni.

Gallagher, C.M. (2005). Pemulihan Pasca Operasi Caesarea. Jakarta: Penerbit Erlangga.

Gant, N., \& Cunningham, F. (2010). Dasar-dasar Ginekologi dan Obstetri. Jakarta: EGC.

Grace. (2007). Faktor-faktor yang Berperan Meningkatnya Angka Kejadian Sectio Caesarea. Ejournal Keperawatan (e-Kp). Volume 2, Nomor 1, Februari 2014.

Hastono, S.P (2007). Analisis Data Kesehatan. Depok : FKM UI.

Hawari, D. (2001). Manajemen Stress, Cemas dan Depresi. Jakarta: Balai Penerbit FKUI.

Hidayat, A.A. (2007). Metodologi Penelitian Teknik Analisa Data. Jakarta: Salemba Medika.

Kusumawati, F., \& Yudi, H. (2010). Buku Ajar Keperawatan Jiwa. Jakarta : Salemba Medika.

Medforth, J. Dkk. (2011). Kebidanan Oxford. Jakarta: EGC. 
Musbikin, I. (2009). Kehebatan Musik Untuk Mengasah Kecerdasan Anak. Yogyakarta: Power Books (IHDINA).

Oxorn, H., \& Forte, R.W. (2010). Ilmu Kebidanan Patologi \& Fisiologi Persalinan: Human Labor \& Birth. Yogyakarta: CV ANDI OFFSET.

Potter, P.A., \& Perry, A.G. (2005). Buku Ajar Fundamental Keperawatan: Konsep, Proses, dan Praktik. Jakarta: EGC.

Prabowo, H., \& Regina, H.S. (2007). Tritmen Meta Musik Untuk Menurunkan Stress. http://repository.gunadarma.ac.id

Smeltzer, S.C., \& Bare, B. (2002). Buku Ajar Keperawatan Medikal Bedah Brunner \& Sudadarth vol. 1. Jakarta: EGC.
Sofian, A. (2012). Sinopsis Obstetri. Jilid 2. Jakarta: EGC.

Stuart (2007).Buku Saku Keperawatan Jiwa.Jakarta : EGC.

Sutrimo, A. (2013). Pengaruh guided imagery snd music (GIM) terhadap kecemasan pasien pre operasi sectio caesaria (sc) di RSUD Banyumas. Skripsi, Universitas Jendral Soedirman.pdf.

Widyastuti, P. (2004). Manajemen Stress. Jakarta: EGC.

Wijaya, P. (2008). Terapi Musik Untuk Mengurangi Rasa Sakit Saat Persalinan.

http://www.tanyadokteranda.com 